MATEC Web of Conferences 53, 02003 (2016)

DOI: $10.1051 /$ matecconf $/ 20165302003$

(C) Owned by the authors, published by EDP Sciences, 2016

\title{
Decentralization as a Cause of Spatial Segregation
}

\author{
Ema Alihodzic Jasarovic ${ }^{1, a}$, Dragan Komatina ${ }^{1}$ and Sanja Paunovic Zaric ${ }^{1}$ \\ ${ }^{1}$ Faculty of Architecture, University of Montenegro, 81 000, Podgorica,
}

\begin{abstract}
City represents an incomplete dynamic process prone to the expansion with a causal link between urban expansion and socio-spatial segregation. The socio-spatial distribution in the city is mostly related to the increased social polarization and inequality. There is a clear connection between divided society and divided city: if society is divided, urban space must be divided. It is the question of the relations between the social inequalities on one hand, and spatial segregation on the other. In the last 10 years, Podgorica is the city that shows alarming statistic values when it comes to demographic trends and the influx of the residents from the northern municipalities, which necessarily causes the city sprawl. Past experiences show that city is unevenly expanding, creating new functions and zones expressed by socio-spatial differences. The beginning of this process lies in modernist conception of the city, by which city was mostly developed, while the current functional organization is based on the same concept. With the first urban plans, which carried similarproblems mentioned in previous section, Podgorica was divided into three clearly differentiated zones: Stara Varoš, Nova Varoš and Novi grad, which became a platform for hierarchical divisions within the space, reflecting them in the society.
\end{abstract}

\section{Introduction}

This paper analyzes the issue of socio-spatial transformation of the modern city that has emerged as a result of very complex processes, starting with the industrialization and development of the tertiary activities, which have provoked uncontrolled urbanization process. Dynamic demographic growth, which is reflected in the immigration population in the cities, a new lifestyle and increase in life standards, introduction of new traffic networks, the causes which influence spatial expansion of the city and increase the distance and the proximity of the city $[1,2,3]$. These and similar processes cause structuring of the city into smaller parts, with distinct centers and sub-centers, deployed in accordance with the spatial organization of the city. In modern urban concepts, the prevailing network system of the centers is polycentrism, which is the opposite approach to former monocentric organization of the city. Polycentric systems emerge as a modern city needs to create a number of urban centers, whereby such spatial organization is "functional or sociological imperative that creates a balance in life of the city" [1].

The initiated process of globalization as a form of postcolonial imperialism is increasing social inequality. The question of socio-economic and spatial separation in cities is one of the most popular research topics in the last ten years. The key question relates to whether the evolution of changes through the expansion of the city and the creation of a polycentric system necessarily leads to spatial

${ }^{\mathrm{a}}$ Corresponding author : aema@t-com.me

This is an Open Access article distributed under the terms of the Creative Commons Attribution License 4.0, which permits unrestricted use, distribution, and reproduction in any medium, provided the original work is properly cited. 
segregation? Numerous authors have attempted to explain the relationship between the occurrence of a new social order and spatial divisions, particularly in global cities. The topic of research is directed towards questioning whether due to all these processes, our cities changed the physiognomy of the class, and what is the structure of the modern city [4]. By observing the historical genesis of the development of the city, there is no city in the history of architecture which has not been divided into rich and poor. Having this fact in mind, spatial separation is a logical outcome of social polarization and inequality. Often the differences are occupied to a larger extent, which leads to the marginalization of area and creation of spatial stigma and is labeling a group of people belonging to it completely $[5,6]$. This paper also questions whether there are positive aspects of this phenomenon, considering that spatial segregation can contribute significantly to the local or regional recognition. Taking into account that the complexity of the city lies in the spatial relationship of opposed social groups, thus inequality becomes an indelible part of the urban area, and very often has a dominant characteristic $[7,8]$.

Nowadays the cities play a strategic role in the new urban hierarchy, and an increasing amount of literature is dedicated to the understanding of the links between the contemporary globalization and socio-spatial transformation which is particularly evident in cities over the past 30 years. Actuality, but also the significance of the subject of polycentric city and decentralization, and the city's role in promoting its development and competitiveness of its parts, currently deserves special attention and a meaningful urban concept [9-11].

\section{Expansion of the city and the emergence of decentralization. Criticism of the functional city}

Up until the seventeenth century the cities were static, enclosed by walls, with no possibility of expansion within that area. The walls were a kind of urban development regulator with an important role in the design of their building. As population increased, many cities felt the need to expand, whereby walls obstructed the further urban development and expansion of the city. The decline of the city walls, in symbolic and functional sense, marks the beginning of an uncontrolled expansion of the city towards an open free space, causing the displacement of the center, and the emergence of decentralization [12]. The most significant from that period is a radical reconstruction of Paris, then Vienna and Barcelona, which solved the problem of urban expansion by demolishing the walls and introducing the new traffic system $[13,14]$.

The nineteenth century will be remembered as the period in which the turbulent economic and social situations happened, closely associated with urbanization, which marked a new era. The industrial revolution created the tremendous changes in demographics of population, as in the very concept of the functional organization of the new city. Most noticeable consequence of this whole process is the transformation of the city in terms of migration of population from rural to urban areas. Industrial urbanization denied the traditional values of the city, moving geographical expansion and leading to the creation of a new, industrial city. Henri Lefebvre indicates that the "critical stage" in the foundation of industrial urbanization has crucially changed the nature of the city and transformed it into a new, far more complex entity: urban [2].

On the fourth CIAM congress (Congress International d'Architecture Moderne) in 1933, the Athens Charter was adopted when the area of interest of CIAM was spreading to urban planning and principles of "functional city", carrying out the analysis by using the example of 33 cities. The result of this research suggested that cities need to be organized according to the principle of strict functional zoning, while the fragmentation process is reflected in the five key functions in urban areas, namely: residence, work, recreation, transportation and central functions. The fragmented areas of the city, with a certain role and function, are mutually classified by the hierarchy [15].

The modernist concept of the city eliminates the former principles of urban city space. The concept of a functional city is often criticized because of the large number of failures that have been proven in practice. New functionalist vision of the city based on the accurate and defined redistribution of the functions, leads to the disappearance of certain urban areas, and this is usually 
reflected through the loss of the main square and streets. By analyzing the problems of the city in the twentieth century, on a concrete example of Frankfurt, Shadrach Woods said that it is not possible to create city by an urban zoning; with the mere separation of functions, their interdependence is ignored [3]. The spacial continuum of the city is disturbed by the new distances and proximities, new proportions which cause the new means of transport, as a result of zoning. Therefore, the loss of continuity of urban space could mean its symbolic destruction. During the last congress of CIAM in Dubrovnik in 1956, Alison and Peter Smithson raised objections to the dogmatism of the Athens Charter and highlighted the problem of the alienation of the population in the new modernist settlements $[16,17,18]$.

The modernist urban planning is based on the idea that the city should be transformed into a single homogeneous entity divided into functional zones. However, this concept has turned entirely into something else. Instead of overcoming the differences, the forms of functional fragmentation of space became the perfect tool for creating the inequality. Demolition of the housing block "Pruitt- Igo" (Pruitt Igoe Housing architect Minoru Yamasaki), is a typical illustration of the idea in which the most important postulates of modern planning were applied and what Charles Jencks views as a moment in which the modern dies [4]. Figure 1.
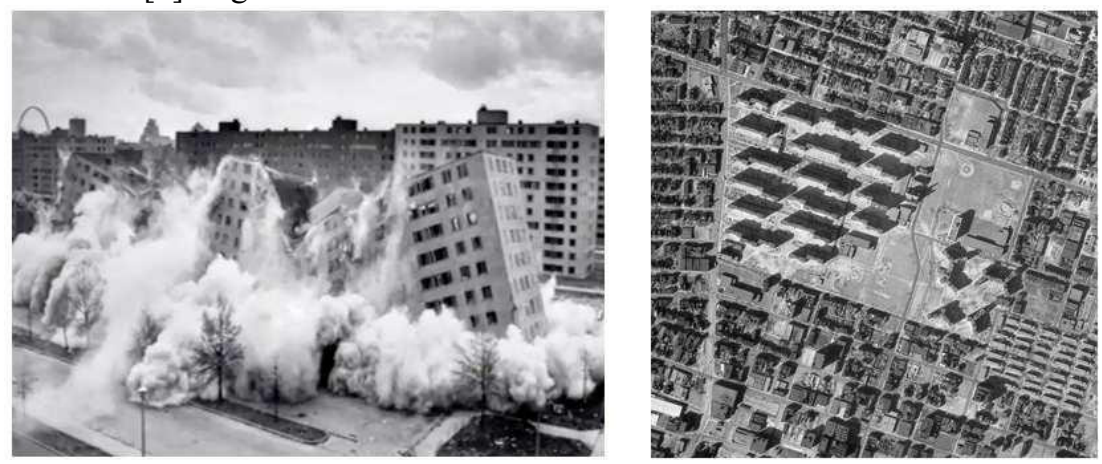

Figure 1. Iconic demolition of the Pruitt-Igoe housing project in St. Louis [22].

Although this residential complex was designed in accordance with the most progressive ideals of CIAM, the explanations for the failure of Pruitt Igoa are very complex. The project has been known for a notable segregation policy, which included other problems in crime, poverty, problems of anonymity, public-private relationships, and many others. After years of devastation, in the end it resulted in demolition. Pruitt-Igoe is one word for a social experiment [19].

Today - the dynamic city is subjected to a constant change. Due to the continued growth and fluidity of cities, there is a constant adjustment of functions of the city, and the creation of new urban zones. In this constant variability, the question is how to maintain the continuity in the functional space and socio-economic transformations. Constant Nieuwenhuys believes the expansion of the city cannot be stopped as it would be an attempt to stop the overall historical development, and that the reasons which led to the expansion of the city still continue to exist, regardless of the redistribution of the functions [6]. Ebenezer Howard said when the city that once reached the optimal size no longer needs to be enlarged, but it needs to fit into a complex system of balance and functional completeness. He was against the chaotic growth of the city, and believed that the city should be planned and considered as a whole [1].

In the mid XX century there have been multi-million cities as a historical novelty. New technological developments have caused different concepts of building cities, questioning the experiences so far. In writing about the disappearance of urban space by building cities of the XX century, many theorists are trying to oppose their views to this uncontrolled development of the city. The reasons for the problems in the city expansion are to be found in the functional structures that are able to withstand the degree of mobility that requires the ten-million city. The goal is always the same, to find a successful model that will lead to the creation of a new urban spatial order, which will maintain an open organization and spontaneous mobility of modern society [20]. 


\section{Division of space - Polycentric system of organization of the city}

As mentioned previously, with the expansion of the city, the first divisions of space were formed. The division of the city had different phases throughout the history. The first significant division of space was on village and town, city or suburb, which dates back to the ancient city. Looking at the genesis of the city, we can come to the conclusion that the city was, even in Mesopotamia, divided into quarters. Furthermore, the Roman city was divided into quarters, with their smaller centers, while medieval towns were divided into residential districts or parishes [21]. Even in the thirties, the theories suggested that the city should be separated into groups of distinct area and shape, which are part of the hierarchical whole. Michel Foucault notes that in the Middle Ages, there was a hierarchical system of places that were sacred, profane and protected, and in contrast, open and undefended, city areas [8]. This mixture of places in the hierarchy is characteristic of the medieval urban space in particular.

Today, with the growth and expansion of the city, the development of suburbs is gaining more significance and the city ceases to be an accurately limited spacial entity. Between 1940 and 1980 the city was divided to the center and the periphery, where, the rich and middle classes lived in the center, and the poor on the outskirts and dangerous periphery. The city center has always been the focal point in the life of the city and a place of exchange of social activities. Formerly it was symbolized by the agora, churches, and cathedrals, and was most vividly described in the medieval towns, where this space represented a type of a set for various civic and religious ceremonies .

The process of densification and expansion (implosion and explosion) of cities created new spatial formations and changed the previous concept of modern urban city. With urban growth and population, spatial differences were decreasing, and these parts of the city were getting closer. These and similar processes condition the city to structure into smaller parts, with special centers and subcenters, deployed in accordance with the spatial organization of the city. ,, The new concepts stimulate the diffused polynuclear development of the cities, so that the new centers become functionally structured, in order to generate a certain hierarchy order and some sort of continuity with the central urban area ", writes Mirko Maretić [1].

The concept of polycentric organization of space occurs even in medieval towns. Each square represents the city center of a specific function, carrying the visual accent that is represented by an architectural object. Today the theory of multiple centers is a tendency, with distributed activities or functions, whereat the centers are placed in the system of hierarchy, according to their roles and size. The functionalized city zones are made in such a manner, which creates a single organism, and within that organism they have their spatial autonomy and recognition. In order the city to function on the basis of a polycentric organization, the communication between its constituent parts must not be compromised. This is implying that within this structure, there is a dominant center, and that all others are in such a connection that does not create a competitive image, and ruins the basic functions of the city. However, spacial situations are not always predictable, they occur as a synergy of different circumstances. With such conscious or unconscious (random) formation of secondary centers, decentralization leads to relocation of certain content, or creates new ones, which often entails specific target groups and space users, which in most cases may lead to social segregation.

\section{Space as a reflection of the society. Socio - spacial segregation}

Based on the assumption that the city is a mirror of society and social activities, and that all phenomena in the city are dependent from each other, Ranko Radović stated that the social connections and the lifestyle are the main generators of urban form, he says: "City expresses life "[9]. The space is a reflection of society and social activities, which implies that the hierarchy in space is closely connected with the hierarchy of the society, which is a basis for the spacial segregation. The spatial practices, representations of space and spatial representation, appear as interdependent, simultaneous variables / dimensions that create the totality of social space [10]. The question is whether the expansion of the city, that knowingly or unknowingly, causes decentralization and the 
creation of a polycentric system necessarily leads to spatial segregation? Frederico Roman Ramos and Ciro Biderman in Urban sprawl and spatial segragation in Sao Paulo, with the use of numerous measurable results, showed that the urban sprawl causes segregation, where the indexes indicate that the emerging parts enhance the segregation [11].

Even Socrates in his "Republic" wrote on the emergence of spatial segregation in the ancient Greece, where the polis, was divided into two cities poor and rich. In contrast, in the ancient Rome there was a spatial integration between rich and poor as a result of special anti-separational spatial planning policy. Sreten Vujović on the development of modern cities and the segregation claims it is the inevitable result of this process, which moves mainly in two directions: spontaneous and organized [12]. It can be said that the segregation inside Montenegrin towns that previously existed based on ethnic and religious grounds, now gives way to a segregation which mainly stems from the socioeconomic inequalities. In Podgorica urbanism, we have witnessed an emphasized form of that phenomenon in the last 20 years which is represented with the housing blocks in which the inhabitants live in poverty, and new housing blocks where visibly affluent class population lives. The choice of location in the city imposes the investment cost, which quite naturally defines the clienteles and customer financial solvency, consciously producing a concept of socio - spatial inequality and segregation. One of the greatest examples of socio - spatial segregation in the world is Sao Paulo; the walls were erected between rich and poor blocks, so today it is the city walls, that Teresa Caldeira writes about [13]. (Figure 2). The established enclaves were created that represent a new alternative for urban livingof the middle and high classes and as such are considered as status symbols, deepening the social distance and encouraging social differences and inequalities. They are physically and functionally introverted and turned inward, defining the outer world as negative.

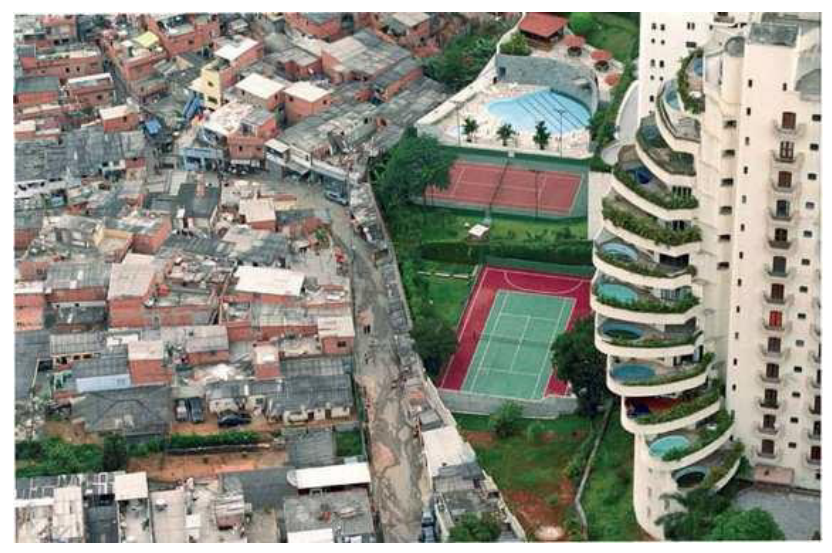

Figure 2. Sao Paulo [23].

The modern city is represented as an incomplete process which brings class, ethnic and racial segregation by growing, and thus forming socially fragmented cities. The city is socially heterogeneous from the village, and therefore all forms of social differentiation are highlighted in the urban than in rural areas. In microcontext and emerging urban planning of Podgorica, the process of social stratification in commodity and monetary economy, it is mostly reflected in urban sphere through the phenomenon of segregation. Consequently today we have parts of the city such as Konik where Roma and refugee populations live, then Stari Aerodrom with the sole function of "dormitory" without any additional content, labeled for a group of residents who immigrated from the north; and the elite parts the city with ambassies, residential complexes of politicians and wealthy citizens as Malo Brdo or the latest residential and business complex Atlas Capital center. (Figure 3). Segregation is defined as space and content in the form of the reserved part of the city. Setha Low writes about "divided city", where this term, in the anthropological sense, refers to the hidden racial and class barriers written in metaphors such as "residential neighborhood" (uptown), "the business part of the city" (downtown), "tony parts" and "ghetto" [15-18]. 
This image cannot but remind on the Berlin Wall as the most famous example of the socioeconomic divisions between eastern and western parts of the city. Spacio-social sense divisions are particularly marked in the cities of the United States, between Afro-American and Caucasian race.
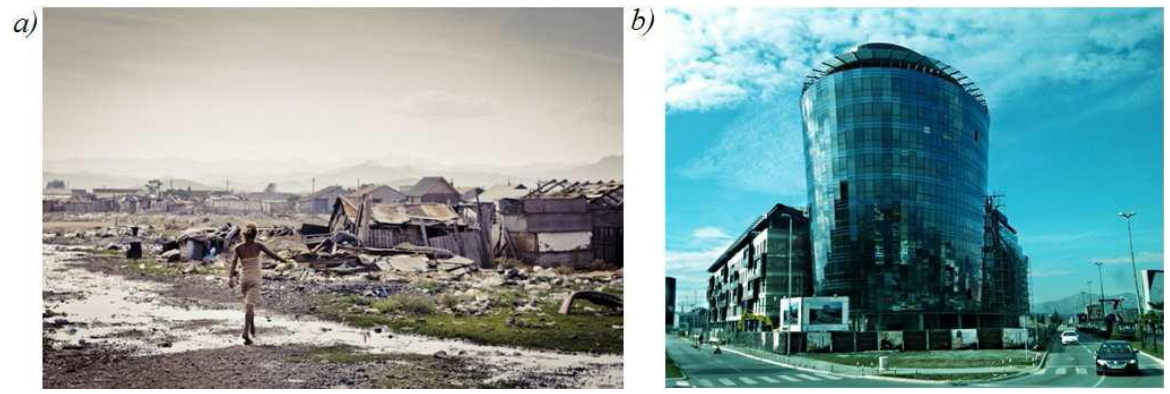

Figure 3. a) Konik, Podgorica [24]; b) Atlas Capital Centar, Podgorica.

The dynamics of widening the differences and division of space with respect to them can create the ethnic city, which is the area that can be economically, socially and linguistically completely independent. Segregation along ethnic lines is also visibly expressed in our cities, particularly during the period after the '90s war. The examples are Gypsy mahalas, then individual locations of Albanians from Kosovo, but also Serbs and Montenegrins in Kosovo, Bosnians in Slovenia etc.

\section{Summary}

The city is a complex, constant and incomplete process. Dynamic changes in the demographic and spatial growth of the modern city, affect its functional organization. Consequently, cities with the specific expansion both vertically and horizontally, change the urban concept over the time. In this regard, the paper will highlight the problem of spatial segregation and alienation of the population which is the idea of a functional city, as it continues to exist through the concept of polycentric cities. This was a clear message that the rationality of the organization of the city did not offer good results. This principle of urbanism is characterized as a new form of organizing the social differences and creation of segregation, contrary to the idea of urbanism that turns the city into a single homogeneous entity eliminating differences. Along with the aforesaid, the neoliberal globalization process, emphasizing the hierarchical divisions, deepens and inaugurates a new concept of the divided city. Due to the extreme inequalities, the town itself produces a new urbanism that is reflected in the significant spatial divisions and forms of behavior in cities. Socioeconomic

polarization and inequality pollute the space giving birth to a new idea of a city. The city becomes a complex process and structure that is imprisoned in the model of duality between conflicting social spaces. All this implies an unbreakable bond between the divided society and the divided city.

\section{References}

1. M. Maretić, Gradski centri, (Zagreb (1996)

2. N. Lefebvre, From the City to Urban Society, (Orion art, Belgrade, (2003)

3. S. Woods, Frankfurt: The Problems of a City in the Twentieth Century, (Studio Vista, London, (1964)

4. C. Jencks, Nova paradigma u arhitekturi, (Orion art, Beograd (2007).

5. http://www.thepolisblog.org/2012/01/management-as-design-in-urban-housing.html

6. C. Nieuwenhuys, G. Debord, Architecture and arts, (Skira editore, Milan, (2004)

7. M. Perovic, Antologija teorije arhitekture XX vijeka, (Građevinska knjiga, Belgrade (2009)

8. M. Foucault, Of Other Spaces, Utopias and Heterotopias, (Diacritics, Belgrade, 2010)

9. G. Radović, Forma grada. Osnove, teorija i praksa, (Građevinska knjiga, Beograd (2009) 
10. H. Lefebvre, The production of space, (Blackwell Publishers, Oxford (1991)

11. G. Radovic, V. Murgul, N.I. Vatin, Applied Mechanics and Materials, 584-586, 564-569 (2014)

12. S. Popović, N. Djurovic, V. Murgul, Procedia Engineering, 117, 832-840 (2015)

13. V. Murgul, Journal of Applied Engineering Science, 12 (2), 121-128 (2014)

14. G. Radovic, V. Murgul, N. Vatin, E. Aronova, Applied Mechanics and Materials, 627, 357-364 (2014)

15. Y. Nikitin, V. Goryunov, V. Murgul, N. Vatin, Applied Mechanics and Materials, 680, 504-509 (2014)

16. R. Alihodzic, V. Murgul, N. Vatin, Applied Mechanics and Materials, 680, 494-498 (2014)

17. G. Radovic, V. Murgul, N. Vatin, Applied Mechanics and Materials, 641-642, 634-638 (2014)

18. V. Murgul, N. Vatin, I. Zayats, Procedia Engineering, 117, 824-829 (2015)

19. V. Murgul, Procedia Engineering, 117, 808-818 (2015)

20. V. Goryunov, I. Zayats, T. Konjkova, V. Murgul, Procedia Engineering, 117, 825-831 (2015)

21. I. Zayats, V. Murgul, Procedia Engineering, 117, 706-711 (2015)

22. http://lsecities.net/media/objects/articles/worlds-set-apart/en-gb/ (12.01.2016)

23. http://www.scielo.br/img/revistas/ccrh/v23n59/05f01.jpg (12.01.2016)

24. http://ngm.nationalgeographic.com/ngm/photo-contest/2011/entries/122822/view/ (12.01.2016) 